\title{
METODE DISKUSI DAN TANYA JAWAB DALAM PEMBELAJARAN SKI UNTUK MENINGKATKAN KEAKTIFAN BELAJAR SISWA KELAS VII - H MTS AL- MAHRUSIYAH LIRBOYO KEDIRI
}

\author{
Ahmad Masrukin \\ Institut Agama Islam Tribakti Kediri \\ ahmadmasrukin4@gmail.com \\ Ahmad Arba'i \\ Institut Agama Islam Tribakti Kediri \\ arbaiakhyar.aa@gmail.com
}

\begin{abstract}
.
This research article aims to determine the increase in student activity in the learning process in class VII $\mathrm{H}$ Mts Al Mahrusiyah Lirboyo Kediri by using learning methods in the form of discussion and question and answer methods. This research is classroom action research (PTK). The data collection technique is observation with descriptive qualitative and quantitative analysis techniques. The results of this study are: (1) Teachers in the learning process question and answer method in the first cycle, and there is a response from students from the questions asked, (2) in the second cycle of the 3rd and 4th meetings the teacher starts to apply the method of discussion and question and answer, in this cycle the activity and enthusiasm of students in learning increased. This can be seen as an increase in the number of students active in the pre-cycle, cycle I and cycle II. And increasing student learning activeness has increased from $7.14 \%$ to $53.57 \%$.
\end{abstract}

\begin{abstract}
Abatrak
Artikel penelitian ini bertujuan untuk mengetahui peningkatan keaktifan siswa dalam proses pembelajaran pada kelas VII H Mts Al Mahrusiyah Lirboyo Kediri dengan menggunakan metode pembelajaran berupa metode diskusi dan Tanya Jawab. Penelitian ini adalah penelitian tindakan kelas (PTK). Teknik pengumpulan data yakni observasi dengan teknik analisis kualitatif dan kuantitatif deskriptif. Hasil dari penelitian ini yaitu: (1) Guru dalam proses pembelajaran metode tanya jawab pada siklus I, dan terdapat respons dari siswa dari pertanyaan yang diajukan, (2) pada siklus II pertemuan ke 3 dan 4 guru mulai menerapkan metode diskusi dan tanya jawab, pada siklus ini keaktifan dan antusias siswa dalam belajar mengalami peningkatan. Hal ini dapat dilihat adanya peningkatan jumlah siswa yang aktif pada pra siklus, siklus I dan siklus II. Dan peningkatan keaktifan belajar siswa tersebut mengalami peningkatan dari 7,14\% menjadi 53,57\%,
\end{abstract}

Kata kunci: Aktif, Metode Diskusi, Metode Tanya Jawab.

\section{Pendahuluan}

Dalam Proses Belajar Mengajar (PBM), kegiatan tersebut merupakan suatu proses pokok yang harus dilalui oleh seorang pendidik dalam hal ini adalah seorang guru. Guru memiliki tanggung jawab atas keberhasilan suatu tujuan pendidikan yang diharapkan. Atas peran sertanyalah mutu pendidikan akan menurun atau bahkan meningkat. Karena sebagai seorang guru memiliki wewenang dalam menyusun dan menciptakan suatu proses pembelajaran agar dapat diterima oleh siswanya dengan menarik dan menyenangkan. Selain itu guru atau tenaga pendidik adalah ujung tombak dalam mencerdaskan kehidupan bangsa, 
melalui berbagai jenis, jalur dan jenjang pendidikan. ${ }^{1}$ Guru sangatlah berperan besar dalam dunia pendidikan eksistensi guru dalam dunia pendidikan merupakan hal yang tak bisa dinafikan lagi keberadaannya.

Didalam proses pembelajaran mengikutsertakan peserta didik secara aktif dapat berjalan efektif, bila pengorganisasian dan penyampaian materi sesuai kesiapan peserta didik. Sebagai seorang guru harus memilih suatu metode mengajar yang tepat. Metode diskusi kelompok bertujuan memberikan kesempatan kepada tiap tiap peserta didik untuk mengembangkan kemampuan memecahkan masalah secara rasional. Dengan keterlibatannya, peserta didik mampu menerima konsep yang disampaikan, dan mampu meraih prestasi yang diharapkan. ${ }^{2}$ Dengan kata lain dengan diterapkannya metode diskusi siswa akan lebih berperan aktif dalam proses pembelajaran.

Begitu juga yang disampaikan oleh Abdul Rachman Shaleh bahwa metode diskusi adalah suatu cara penguasaan bahan pelajaran melalui wahana tukar pendapat berdasarkan pengetahuan dan pengalaman yang telah diperoleh, guna memecahkan suatu masalah. ${ }^{3}$

Ketika peneliti melakukan Praktik Pengalaman Lapangan (PPL)di Mts Al Mahrusiyah Lirboyo Kediri peneliti melihat tidak selamanya hasil belajar siswa yang menggunakan metode ceramah memiliki hasil yang kurang

1 Asep Suryana, Suryadi, Pengelolaan Pendidikan, (Jakarta: Direktorat Jenderal Pendidikan Islam Departemen Agama Republik Indonesia, 2009), Cet. I, h. 188.

2 Sumarni, Abduh H.Harun, dan Imran. "Penerapan Metode Diskusi Untuk Meningkatkan Hasil Belajar Siswa Kelas IV Sekolah Dasar Kecil Toraranga Pada Mata Pelajaran PKn Pokok memuaskan. Begitu pula sebaliknya, tidak selamanya hasil belajar siswa yang menggunakan metode diskusi dapat mencapai hasil yang maksimal. Sehingga peneliti berkeinginan untuk mengamati proses pembelajaran yang dilakukan didalam kelas yang menggunakan metode ceramah dan metode diskusi.

Kesuksesan belajar siswa tidak hanya tergantung pada intelegensi anak saja, akan tetapi juga tergantung pada bagaimana pendidik menggunakan metode yang tepat dan memberinya motivasi. Banyak cara yang dapat dilakukan untk memberikan motivasi kepada anak didik diantaranya adalah memberi angka atau nilai. Pemberian mulai dilakukan oleh guru ketika mereka selesai ulangan atau menjawab pertanyaan yang diberikan oleh guru. Cara ini merangsang anak untuk giat belajar. Anak yang nilainya rendah, mereka akan termotivasi untuk meningkatkan belajarnya dan anak yang nilainya bagus akan semakin giat dalam belajar.

Maka untuk meningkatkan aktivitas dan semangat belajar diperlukan ketrampilan dan kreativitas guru dalam menyampaikan materi yaitu dengan cara penggunaan metode yang tepat dan motivasi. ${ }^{4}$

Sejarah memiliki peran yang sangat penting dalam kehidupan. Dengan sejarah orang akan mengetahui keadaan masa lalu yang mengandung banyak nilai dan pelajaran bagi hidup seseorang. Menurut Kontowijoyo, mengemukakan

Bahasan Sistem Pemerintahan Kabupaten, Kota dan Provinsi”. Jurnal Kreatif Tadulako Online Vol. 3 No. 4. (2015). h. 15

3 Abdul Rachman Shaleh, Pendidikan Agama dan Keagamaan (Jakarta Pusat: PT. Gemawindu Pancaperkasa, 2000), h. 62

${ }^{4}$ Sardiman. Interaksi dan Motivasi Belajar Mengajar. (Rajawali, Jakarta. 2004). h. 76 
bahwa sejarah bukan hanya untuk mengenang masa lalu, sejarah diharapkan mampu memberikan sumbangan yang besar terhadap realitas kehidupan sekarang. Dan diharapkan kehidupan sekarang dan yang akan datang dapat berkaca pada peristiwa pada masa lalu. ${ }^{5}$

Oleh karena itu, berpijak pada permasalahan di atas penulis kira perlu sekali menerapkan metode diskusi dan tanya jawab, penerapan metode diskusi dan tanya jawab ini dilakukan pada kelas VII H Mts Mahrusiyah Lirboyo Kediri.

Berdasarkan latar belakang permasalahan di atas, maka peneliti akan merumuskan beberapa fokus penelitian yaitu sebagai berikut: 1. Apakah metode tanya jawab dan diskusi bisa meningkatkan keaktifan siswa di kelas VII $\mathrm{H}$ Mts Al Mahrusiyah Lirboyo Kediri? 2. Bagaimana penerapan metode diskusi dan tanya jawab pada siswa kelas VII H di MTs Mahrusiyah Lirboyo Kediri? 3. Apakah metode tanya jawab dan diskusi dapat meningkatkan keaktifan siswa pada mata pelajaran Sejarah Kebudayaan Islam dengan menggunakan di kelas VII-H MTs Al Mahrusiyah Lirboyo Kediri?

Dengan penggunaan metode diskusi dan tanya jawab ini di harapkan siswa lebih aktif lagi dalam belajarnya, siswa diharapkan tidak hanya mendengarkan saja melainkan ikut serta dalam berlangsungnya proses pembelajaran.

\section{Pengertian Metode Pembelajaran}

Zakiyah Daradjat mendefinisikan metode (method) adalah suatu cara kerja yang sistematik dan umum, seperti cara kerja ilmu pengetahuan. Ia merupakan jawaban atas pertanyaan "bagaimana". Metode berasal dari bahasa Greeka, yaitu metha berarti melalui atau melewati dan hodos berarti jalan atau cara. Jadi, metode adalah jalan atau cara yang harus dilalui untuk mencapai tujuan tertentu. Sanjaya mengartikan metode adalah cara yang digunakan untuk mengimplementasikan rencana yang sudah disusun dalam kegiatan nyata agar tujuan yang telah disusun tercapai secara optimal. Ini berarti, metode digunakan untuk merealisasikan strategi yang telah ditetapkan.

Sedangkan pembelajaran berasal dari kata instruction yang dalam bahasa Yunani disebut instructus atau intruere yang berarti menyampaikan pikiran. Dengan demikian arti instruksional adalah menyampaikan pikiran atau ide yang telah diolah secara bermakna melalui pembelajaran.

Gagne menyatakan bahwa: "instruction is a set of event that effect learners in such a way that learning is facilitated". Menurut Gagne, mengajar atau "teaching" merupakan bagian dari pembelajaran (instruction), di mana peran guru lebih ditekankan kepada bagaimana merancang atau mengaransemen berbagai sumber dan fasilitas yang tersedia untuk digunakan atau dimanfaatkan peserta didik dalam mempelajari sesuatu.

Metode pembelajaran adalah prosedur, urutan, langkah- langkah, dan cara yang digunakan guru dalam pencapaian tujuan pembelajaran. Dapat dikatakan bahwa metode pembelajaran merupakan jabaran dari pendekatan. Satu pendekatan dapat dijabarkan ke dalam berbagai metode pembelajaran. Dapat pula dikatakan bahwa metode adalah prosedur pembelajaran yang difokuskan ke

5 Kuntowijoyo. Pengantar Ilmu Sejarah. (Yogyakarta : Yayasan Bintang Budaya, 1995), h. 17 
pencapaian tujuan. ${ }^{6}$ Reigeluth mengartikan bahwa metode mencakup rumusan tentang pengorganisasian bahan ajar, strategi penyampaian, dan pengelolaan kegiatan dengan memperhatikan tujuan, hambatan, dan karakteristik peserta didik sehingga diperoleh hasil yang efektif, efisien, dan menimbulkan daya tarik pembelajaran. Pendapat Reigeluth tersebut didukung oleh Jerome Brunner (dalam Conny Semiawan, 1997) dengan menyebut metode pembelajaran induktif atau berpikir induktif. Kemudian J.E. Kemp. menggunakannya untuk mengelompokan pola mengajar dan belajar, yaitu klasikal, mandiri, dan interaksi guru-peserta didik atau pengajaran kelompok.

Berbagai pendapat di atas, menunjukkan bahwa metode berhubungan dengan cara yang memungkinkan peserta didik memperoleh kemudahan dalam rangka mempelajari bahan ajar yang disampaikan oleh guru. Ketepatgunaan dalam memilih metode sangat berpeluang bagi terciptanya kondisi pembelajaran yang kondusif, menyenangkan, sehingga kegiatan pembelajaran (instructional activities) dapat berlangsung secara efektif dan efisien dalam memfasilitasi peserta didik untuk dapat meraih hasil belajar sesuai yang diharapkan. Dengan demikian metode merupakan suatu komponen yang sangat menentukan terciptanya kondisi selama berlangsungnya kegiatan pembelajaran. ${ }^{7}$

Jadi, metode pembelajaran berarti berbagai cara atau seperangkat cara atau jalan yang dilakukan dan ditempuh guru secara sistematis melakukan upaya pembelajaran bisa lebih efektif sehingga bisa memenuhi tujuan pembelajaran yang telah ditetapkan.

\section{Metode Diskusi}

Metode diskusi adalah suatu cara mengajar yang dicirikan oleh suatu keterkaitan pada suatu topik atau pokok pernyataan atau masalah dimana para peserta diskusi berusaha untuk mencapai suatu keputusan atau pendapat yang disepakati bersama maupun pemecahan terhadap suatu masalah dengan mengemukakan sejumlah data dan argumentasi.

Metode Diskusi dapat juga dimaknai sebagai proses pelibatan dua orang peserta atau lebih untuk berinteraksi saling bertukar pendapat, dan atau saling mempertahankan pendapat dalam pemecahan masalah sehingga didapatkan kesepakatan di antara mereka. Ada juga yang memaknai diskusi sebagai percakapan ilmiah yang berisikan pertukaran pendapat, pemunculan ide-ide serta pengujian pendapat yang dilakukan oleh beberapa orang yang tergabung dalam kelompok itu untuk mencari kebenaran.

Meskipun diungkapkan dalam redaksi yang berbeda-beda, substansinya adalah bahwa diskusi dimaksudkan untuk penyelesaian masalah atau mencari kesepakatan dengan didukung oleh argumentasi. Menurut Mc.Keachie dari hasil penelitiannya, dibanding metode ceramah, metode diskusi dapat meningkatkan anak dalam pemahaman konsep dan keterampilan memecahkan masalah. Tetapi dalam transformasi pengetahuan, penggunaan metode diskusi hasilnya lambat dibanding penggunaan ceramah. Sehingga metode ceramah lebih efektif untuk meningkatkan kuantitas pengetahuan anak dari pada metode diskusi. Lebih jauh, diskusi akan bermanfaat untuk hal-hal berikut ini: 
1. Membantu siswa berpikir atau berlatih berpikir dalam disiplin ilmu tertentu.

2. Membantu siswa belajar menilai logika, bukti, dan argumentasi (hujjah), baik pendapatnya sendiri maupun pendapat orang lain.

3. Memberi kesempatan kepada siswa untuk memformulasikan penerapan prinsip-prinsip tertentu.

4. Membantu siswa menyadari dan mengidentifikasi problem

5. lem dari penggunaan informasi dari buku rujukan.

6. Memanfaatkan keahlian (sumber belajar) yang ada pada anggota kelompok.

Selain itu, ketika proses diskusi dilakukan, guru sering menghadapi beberapa hambatan, antara lain sebagaimana berikut:

1. Melibatkan partisipasi siswa dalam diskusi

2. Membuat siswa sadar terhadap pencapaian tujuan pembelajaran.

3. Mengatasi reaksi emosional siswa

4. Memimpin diskusi tanpa banyak melakukan intervensi

5. Membuat struktur diskusi, mulai dari pengantar sampai dengan simpulan.

Berikut ini sepuluh tips tentang bagaimana seorang guru memimpin proses diskusi, antara lain yaitu:

1. Mengungkapkan kembali (memarafrasekan) apa yang dikatakan oleh seorang siswa sehingga siswa tersebut merasa bahwa pertanyaan atau komentarnya dipahami dan siswa lain dapat mendengar ringkasan apa yang telah ditanyakan. Guru dapat mengatakan,"Jadi, Anda mengatakan bahwa....".

2. Mengecek pemahaman guru tentang apa yang dikatakan siswa atau meminta siswa untuk menjelaskan apa yang mereka katakan. Anda dapat
mengatakan,"Apakah

anda mengatakan bahwa....?

3. Memberi pujian atau komentar yang lebih mencerahkan. Dalam hal ini, guru bisa memberi komentar, "Itu ide bagus! saya senang anda mengangkat masalah itu".

4. Mengelaborasi kontribusi siswa dengan memberi contoh atau menyarankan cara baru melihat problem. Anda dapat mengatakan, "Pendapat saudara sangat tepat dari perpsektif kelompok minoritas. Kita dapat juga mempertimbangkan bagaimana kelompok mayoritas memandang situasi yang sama."

5. Memacu diskusi dengan mempercepat tempo, menggunakan humor atau kalau perlu mendorong siswa untuk berpartisipasi dalam diskusi. Guru dapat mengatakan, "Wah, di kelas ini banyak sekali pendiamnya. Tantangan anda sekarang, dalam lima menit ke depan beberapa kata yang bisa anda pikirkan tentang....?"

6. Menolak ide siswa dengan santun untuk merangsang diskusi tetap berjalan. Guru bisa mengatakan,"Saya paham ide saudara, tetapi saya tidak yakin dengan apa yang saudara katakan itu benar adanya. Adakah di antara saudara yang memiliki pengalaman yang berbeda?"

7. Menengahi perbedaan pendapat antara siswa dengan mencairkan ketegangan yang muncul di antara mereka. Anda dapat mengatakan,"Saya pikir sebenarnya antara Aminah dan Tuti tidak bertentangan satu dengan yang lain, tetapi hanya berbeda sudut pandangnya."

8. Menarik ide-ide yang berkembang dan menunjukkan hubungan di antara ide-ide tersebut. Guru bisa 
mengatakan,"Seperti kita dengar dari komentar dan pendapat dari Ahmad, Faid, dan Hartsa, bahwa.....?"

9. Mengubah proses diskusi dengan mengganti cara partisipasi peserta diskusi atau dengan meminta kelompok tampil ke depan. Guru bisa meminta siswa, "Sekarang mari kita bagi kelas ke dalam kelompokkelompok kecil dan kita lihat apakah ...?"

10. Meringkas atau mencatat bila diperlukan, ideide penting yang berkembang dalam diskusi di kelas. Anda dapat mengatakan, "Saya telah mencatat tiga ide penting yang muncul bahwa....."8

\section{Metode Tanya Jawab}

\section{Pengertian Metode Tanya jawab}

Kegiatan belajar, memang peranan yang penting. Sebab pertanyaan yang tersusun dengan baik dengan tekni $\mathrm{k}$ pengajuan yang tepat akan meningkatkan partisipasi dan prestasi siswa dalam kegiatan belajar, membangkitkan minat dan rasa ingin ta hu siswa terhadap masalah yang sedang dibicarakan, mengembangkan pola pikir dan belajar aktif siswa sebab berpikir itu sendiri sebenarnya adalah pertanyaan; menuntun proses belajar siswa, sebab pertanyaan yang baik akan membantu siswa dapat menentukan jawaban yang baik, memusat-kan perhatian siswa

Menurut Armai Arief, metode Tanya Jawab adalah suatu teknik penyampaian pelajaran dengan cara guru mengajukan pertanyaan. Atau suatu metode di dalam pendidikan di mana guru bertanya sedangkan siswa menjawab tentang materi yang ingin diperoleh. ${ }^{9}$
Berdasarkan paparan di atas, dapat diambil kesimpulan tentang pengertian metode Tanya Jawab ialah suatu metode mengajar yang dijadikan adanya komunikasi langsung di mana guru mengajukan pertanyaan-pertanyaan dan siswa menjawab tentang materi yang diperolehnya atau sebaliknya siswa bertanya dan guru menjawab sehingga siswa termotivasi.

Pengertian itu menunjukkan bahwa metode Tanya Jawab itu diperlukan adanya komunikasi langsung antara guru dan siswa sehingga tidak hanya terjadi komunikasi satu arah saja. Namun dalam komunikasi ini terlihat adanya hubungan timbal balik secara langsung antara guru dan siswa, bahkan siswa dan siswa. Karena ketika siswa memberikan jawaban yang tepat dapat mendorong siswa yang lainnya untuk memberikan tanggapan dan mengajukan pertanyaan.

Dengan demikian metode Tanya Jawab merupakan ucapan verbal yang meminta respon dari seseorang yang ke nai respon yang akan diberikan dapat berupa pengetahuan sampai pada hal-hal yang merupakan hasil pertimbangan. Jadi, bertanya merupakan stimulasi efektif yang mendorong kemampuan berpikir. Metode Tanya Jawab di sini dimaksudkan untuk mengenalkan pengetahuan, fakta-fakta tertentu yang sudah diajarkan dan untuk merangsang perhatian siswa dengan berbagai cara-cara (sebagai appersepsi, selingan dan evaluasi).

\section{Tujuan metode Tanya jawab}

Adapun tujuan penggunaan metode tanya jawab dalam kegiatan belajar mengajar adalah untuk:

9 Armai Arief, Pengantar Ilmu dan Metodologi Pendidikan Islam, (Jakarta: Ciputat Pres, 2002), hlm. 140. 
a. Menyimpulkan materi yang telah lalu.

Setelah guru menguraikan suatu persoalan, kemudian guru mengajukan beberapa pertanyaan. Pertanyaan-pertanyaan itu dijawab oleh siswa, sedangkan hasil jawaban siswa yang betul/benar disusun dengan baik sehingga merupakan ikhtisar pelajaran yang akan menjadi milik siswa.

b. Melanjutkan pelajaran yang sudah lalu. Dengan mengulang pelajaran yang sudah diberikan dalam bentu $\mathrm{k}$ pertanyaan, guru akan dapat menarik perhatian kepada pelajaran yang lalu.

c. Menarik perhatian siswa untuk menggunakan pengetahuan dan pengalaman.

d. Memimpin pengalaman atau pemikiran siswa. Ketika siswa menghadapi suatu persoalan maka pemikiran siswa dapat dibimbing dengan mengajukan pertanyaanpertanyaan atau seorang siswa yang tidak memperhatikan pembicaraan guru yang dapat meng-usahakan supaya perhatiannya kepada keterangan-keterangan guru dengan mengejutkan dengan memberikan dengan memberikan beberapa pertanyaan.

e. Menyelangi pembicaraan untuk merangsang perhatian siswa dalam belajar sehingga dengan demikian ada kerjasama antara siswa dengan guru dan dapat menimbulkan semangat siswa.

f. Meneliti kemampuan siswa dalam memahami suatu bacaan yang dibacanya atau ceramah yang sudah didengarnya. ${ }^{10}$
Kelebihan dan kekurangan metode Tanya jawab

Efektivitas suatu metode mengajar di dalam kelas dipengaruhi oleh faktor tujuan, faktor siswa, faktor situasi dan faktor guru itu sendiri. Dengan memiliki pengetahuan secara umum tentang sifat berbagai metode, seorang guru akan lebih mudah menetapkan metode yang paling baik atau sesuai dalam situasi dan kondisi pembelajaran yang khusus, dari sekian banyak metode tidak ada satupun yang dianggap paling baik dan paling cocok untuk selalu digunakan. Karena semua metode itu mempunyai metode itu mempunyai keunggulan dan kelemahan tersendiri. Begitu juga dengan metode tanya jawab ini.

menurut Hendayat Soetopo, keunggulan atau keuntungan dari metode tanya jawab, yaitu:

a. Lebih mengaktifkan siswa.

b. Memberikan kesempatan kepada untuk mengemukakan hal-hal yang belum jelas.

c. Dapat mengetahui perbedaan pendapat siswa, sehingga bisa dicari titik temunya.

d. Dapat mengurangi verbalisme.

e. Memberikan kesempatan pada gur u untuk menjelaskan kembali konsep yang masih kabur. ${ }^{11}$

Dari pendapat di atas, maka peneliti dapat menyimpulkan bahw a kelebihan metode tanya jawab ini adalah keadaan atau situasi akan hidup, minat belajar siswa akan bangkit. Hal ini dimaksudkan untuk melatih siswa menjadi lebih berani mengemukakan pendapatnya dan dapat melatih cara berpikir logis dan sistematis. Dengan

11 Hendyat Soetopo, Pendidikan Dan Pembelajaran, (Malang: UMM Press, 2005), hlm. 155. 
demikian guru dapat mengontrol dari hasil kegiatan belajar mengajar.

Metode tanya jawab ini selain memiliki keunggulan juga memiliki kelemahan. dari segi kelemahan metode tanya jawab ini adalah:

a. Apabila terjadi perbedaan pendapat akan banyak untuk menyelesaikannya.

b. Kemungkinan akan terjadi penyimpa ngan perhatian siswa, terutama apabila terdapat jawaban-jawaban yang kebetulan yang menarik perhatiannya, tetapi bukan sasaran yang dituju.

c. Dapat menghambat cara berpikir, ap abila guru kurang pandai dalam penyajian materi pelajaran.

d. Situasi persaingan bisa timbul, apabila guru kurang pandai/ menguasai teknik pemakaian metode ini. ${ }^{12}$

\section{Proses Pembelajaran dengan Metode Diskusi dan Tanya Jawab Paparan Tindakan Pra Siklus 1}

Pada pertemuan pertama guru melakukan tindakan - tindakan pendahuluan seperti halnya mengucapkan salam, perkenalan menanyakan kabar murid, absensi, berdo'a dan lain sebagainya. Setelah pendahuluan selesai guru mulai beranjak memasuki materi Sejarah Kebudayaan Islam, yang mana pada saat pertemuan pertama materi pelajaran sudah mulai memasuki geografis kota yastrib, tentang keadaan ekonomi nya kepercayaan penduduk yatsrib dan juga keadaan sosial budaya kota itu, yang mana mana materi tersebut sudah tercantum dalam silabus dan juga RPP.

Setelah guru membuat peta konsep dengan media belajar berupa spidol dan papan tulis dan guru menjelaskan tentang materi pelajaran, guru memberikan kesempatan kepada siswa untuk bertanya, pada pertemuan pertama ini siswa terlihat belum terlalu antusias dalam belajarnya, eksperesinya pun cukup beragam, ada yang benar benar memperhatikan, ada yang main sendiri, tidak terlalu mendengarkan penjelasan guru, bahkan ada juga yang sampai mengantuk dan kemudian terlelap tidur.

Untuk memancing gairah belajar siswa guru berinisiatif untuk memberikan pertanyaan kepada murid perihal materi yang di sampaikan, dari beberapa siswa ada yang berani menjawab walaupun masih melihat dan mencari jawaban dari LKS yang mereka miliki.

Setelah semua selesai guru memberikan motivasi kepada siswa agar lebih aktif membaca, khusus nya terkait dengan materi pelajaran Sejarah Kebudayaan Islam supaya pengetahuan mereka lebih luas, setelah mengajukan pertanyaan dan evaluasi sejenak barulah setelah itu guru menutup pelajaran dan berdo'a bersama.

\section{Paparan Tindakan Siklus I}

Dalam pertemuan kedua guru melanjutkan materi pelajaran SKI yang pada pertemuan pertama telah diajarkan, tentunya setelah melakukan tindakan pendahuluan berupa salam dsb.

Sebelum guru melanjutkan pada pertemuan kedua ini, terlebih dahulu guru menanyakan materi pada pertemuan pertama dengan tujuan siswa tidak mudah lupa mengenai materi yang telah diajarkan,

Kemudian guru melanjutkan materi SKI mengenai Strategi Dakwah Nabi Muhammad SAW di Madinah, yang mana isinya meliputi Perubahan nama dari Yatsrib menjadi Madinah, Membangun pusat dakwah dan pemerintahan, Mendamaikan suku Aus dan Khadraj dll. seperti yang sudah tercantum dalam RPP.

\footnotetext{
${ }^{12}$ Hendyat Soetopo, h. 158
} 
Pada kali ini guru mulai mencoba menerapkan metode diskusi kepada siswa, pada awalnya guru menerangkan sekilas terkait materi yang akan diajarkan, dengan penyampaian yang tegas dan gamblang agar siswa tak mudah mengantuk, dan perhatiannya lebih terfokus pada guru, setelah itu guru membentuk kelompok dengan jumlah kelompok 4, setiap kelompok beranggotakan 5 siswa, ada juga yang 4, karena ada sebagian siswa yang tidak masuk, setelah itu setiap siswa berkumpul dengan kelompoknya masing masing dan mulai mendiskusikan materi yang dipelajari, dengan pengarahan dan pantauan dari guru tentunya.

Dalam diskusi ini guru memberikan waktu 30 menit untuk mempelajari materi pelajaran bersama anggota kelompoknya, di saat siswa sedang berdiskusi, guru menghimbau kepada murid untuk mencatat poin point penting terkait materi SKI yang di pelajari, setiap siswa wajib mencatat perihal materi yang mereka diskusikan minimal 3 point setiap sub bab, selain itu setiap kelompok dituntut untuk membuat pertanyaan untuk di diskusikan bersama, dengan cara seperti ini lah siswa dituntut aktif dalam belajarnya, dan bisa bertukar pendapat dengan teman sekelompoknya.

Setelah waktu diskusi bersama kelompok selesai, tahap selanjutnya yaitu diskusi bersama antar kelompok, dalam hal ini guru menunjuk salah satu siswa untuk menjadi moderator (pemimpin berjalannya diskusi), tetapi dikarenakan belum siapnya siswa untuk menjadi moderator, pada kali ini guru nya langsung yang berperan sebagai moderator, selain itu guru juga secara tidak langsung memberikan contoh kepada siswa bagaimana cara menjadi moderator yang baik agar pada pertemuan berikutnya siswa sudah siap jikalau ditunjuk sebagai moderator dalam diskusi.

Pada saat berjalannya diskusi dan guru langsung yang berperan sebagai moderator, dan guru mempersilahkan siswa untuk bertanya, setelah ada salah satu siswa yang menanyakan perihal perubahan nama yastrib ke madinah, guru sebagai moderator menyampaikan pertanyaan tersebut kepada para peserta diskusi yang tak lain yaitu para siswa itu sendiri, pada kesempatan ini masih sedikit siswa yang menjawab, bisa jadi hal ini siswa belum berani untuk menjawab dan masih malu malu, tetapi yang jelas metode diskusi ini lebih efektif jikalau dibandingkan dengan metode ceramah yang mana siswa hanya mendengarkan materi yang diterangkan guru.

Dalam hal ini guru dituntut untuk mengembangkan potensi yang dimiliki siswa, guru berinisiatif untuk menanyakan kepada kelompok peserta diskusi, dan mempersilahkan untuk menyampaikan jawabannya, sesuai dengan diskusi kelompok yang dilakukan sebelumnya, perwakilan dari kelompok 1 mulai menjawab di kuatkan lagi oleh salah satu rekan kelompok nya, dan juga di tambah jawaban dari perwakilan kelompok 2, hingga jawaban selesai dan di lanjut pertanyaan berikutnya mengenai isi dari piagam madinah dan seterusnya.

Setelah diskusi selesai guru menyimpulkan pertanyaan pertanyaan yang diutarakan siswa, dan berusaha untuk menjawab pertanyaan pertanyaan tersebut, setelah siswa paham dan dapat menerima kesimpulan dari guru barulah guru menutup pelajaran dengan membaca do'a bersama. Dan sebelum salam dan do'a bersama guru menugaskan kepada siswa untuk membaca materi yang akan dipelajari minggu depan, sehingga ketika masuk siswa sudah siap untuk berdiskusi.

Jika diamati pada pertemuan kali ini siswa sudah mulai aktif dalam belajarnya, terbukti dengan adanya siswa yang sudah mulai berani bertanya, menjawab dan membantu temannya akan jawaban 
tersebut, walaupun memang hal tersebut tak lepas dari bimbingan dan perlunya dorongan dari guru sendiri.

\section{Paparan Tindakan Siklus II}

Pada pertemuan ke 3 siswa harus sudah lebih siap dalam belajarnya, karena pada pertemuan sebelumnya guru sudah menugaskan untuk membaca terlebih dahulu materi yang akan dipelajari di kamar masing - masing sehingga ketika dikelas siswa sudah siap untuk belajar.

Ketika guru sudah mulai memasuki kelas, guru langsung membagi kelompok dengan hitungan 1 sampai 4 yang dilakukan siswa dari pojok kanan, melalui arahan guru siswa berkumpul dengan kelompoknya masing masing dan sudah bersiap untuk melakukan diskusi.

Sebelum diskusi di mulai guru menanyakan terlebih dahulu perihal materi pelajaran yang di baca di kamar masing masing, apakah siswa sudah benar benar membaca atau tidak, mengenai materi yang akan dibahas pada pertemuan ke 3 ini yaitu perihal Substansi Dakwah Nabi Muhammad SAW di Madinah, Menanamkan sendi sendi syariat, Menanamkan sendi - sendi ibadah, Menanamkan sendi - sendi muamalah, Menanamkan sendi - sendi politik dan pemerintahan.

Dari pertanyaan pertanyaan yang diajukan guru, terlihat dari beberapa siswa sudah banyak yang menguasai materi pelajaran, sehingga akan memudahkan proses berjalannya diskusi.

Dalam pertemuan ke 3 ini pula guru sudah menyiapkan beberapa so'al untuk di diskusikan, terkait materi pelajaran yang akan di pelajari, setiap kelompok di beri 4 pertanyaan, sehingga masing masing siswa mendapat tanggung jawab mencari satu jawaban dari pertanyakan yang diberikan guru, setelah itu jawaban jawaban yang ada di diskusikan dengan teman satu kelompok nya, dan setiap kelompok juga menyiapkan
1 pertanyaan untuk di diskusikan dalam diskusi bersama.

Dalam diskusi bersama pada pertemuan ke 3 ini siswa sudah berani untuk menjadi moderator, karena pada pertemuan sebelumnya guru sudah mencotohkan bagaimana tugas dari seorang moderator, meskipun siswa belum benar benar menguasai dalam memimpin berjalannya diskusi.

Tetapi hal ini yang jelas sudah menjadi suatu kemajuan, karena memang harus adanya proses dalam adanya suatu perubahan, setelah semuanya sudah selesai, antara kelompok satu dan lainnya pun sama sama menguatkan jawabannya ketika ada pertanyaan yang di ajukan dari kelompok lainnya, dan suasana diskusi pun berjalan sangat ramai, pada kali ini guru hanya bertugas sebagai fasilitator dalam proses pembelajaran, dan mengarahkan ketika ada suatu hal yang perlu pengarahan dari guru, ketika diskusi antar kelompok pun selesai guru menyimpulkan perihal materi yang dipelajari hari ini, dan juga membantu menjawab pertanyaan yang belum terselesaikan dalam diskusi kelompok tadi.

Pada pertemuan ke 4 guru melanjutkan materi yang belum terselesaikan yaitu mengenai Tantangan Dakwah Nabi Muhammad SAW di Madinah, Masa Akhir Dakwah Nabi Muhammad SAW di Madinah hingga wafat nya Nabi Muhammad SAW.

Kelompok diskusi yang sudah guru tetapkan pada pertemuan sebelumnya di lanjut pada pertemuan kali ini, sehingga guru tak lagi repot repot membagi kelompok diskusi lagi. Siswa pun dengan sigap berkumpul dengan kelompok nya masing masing dan mulai mendiskusikan materi yang dipelajari, siswa sangat lah antusias dalam belajarnya kali ini.

Siswa saling bertukar pendapat dengan teman sekelompok nya dan 
menyampaikan argumen mereka yang berbeda beda, pada pertemuan ke 4 ini diskusi hanya di cukupkan pada diskusi kelompok saja dan setelah itu guru melanjutkannya dengan melakukan evaluasi.

Dikarenakan pada pertemuan ke 4 ini pertemuan terakhir guru mengajar di Mts mahrusiyah, guru melakukan evaluasi dengan cara membuat so'al, soal tersebut berupa pilihan ganda sebanyak 10 so'al dan untuk so'al essai berjumlah 5 so'al, dan diantara so'al tersebut guru sengaja membuat soal yang yang berbeda beda untuk mengantisipasi siswa yang mencontek kepada temannya. Dari 5 soal tersebut antara lain yaitu:

Ketika nabi hijrah ke madinah nabi membangun masjid Nabawi. Pada bulan apa masjid tersebut dibangun ? dan siapakah orang yang pertama kali merenovasi masjid nabawi,?

Dalam mempertahankan wilayah madinah nabi muhammad berjuang dengan sepenuh jiwa raga, dan banyak perang yang di laluinya, salah satu nya perang badar, Pada tanggal berapakah perang badar terjadi,?

Perang khandak yaitu salah satu peperangan yang melibatkan kaum kafir mekkah dan Yahudi yang tidak senang kepada umat islam, pada peperangan tersebut siapa tokoh yang mengusulkan strategi membangun pertahanan parit (khandak)?

Tujuan dakwah nabi muhammad di madinah diantaranya yaitu menanamkan sendi sendi politik dan pemerintahan dan juga nabi Muhammad mengangkat Mu'awin (wazir) yang bertugas sebagai wakil pembantu Nabi. Siapa dua orang sahabat yang diangkat Nabi sebagai Mu'azin (Wazir)?

Pada masa akhir dakwah nabi di madinah nabi melakukan ibadah haji wada', pada saat itu nabi berkhutbah di depan para pengikutnya dari mekkah dan madinah. Apa isi yang dapat disimpulkan dari khutbah nabi tersebut? Sebutkan satu saja!

\section{Pembahasan}

Pada tahap pra siklus pertemuan pertama guru masih menggunakan metode ceramah dalam proses pembelajaran, selain itu guru juga membuatkan peta konsep terkait pelajaran SKI, menggambar point point penting yang perlu dijelaskan.

Setelah guru membuat peta konsep dengan media belajar berupa spidol dan papan tulis dan guru menjelaskan tentang materi pelajaran, guru memberikan kesempatan kepada siswa untuk bertanya, pada pertemuan pertama ini siswa terlihat belum terlalu antusias dalam belajarnya, eksperesinya pun cukup beragam, ada yang benar benar memperhatikan, ada yang main sendiri, tidak terlalu mendengarkan penjelasan guru, bahkan ada juga yang sampai mengantuk dan kemudian terlelap tidur. Pada tahap ini terlihat siswa masih pasif dalam belajarnya, dan terasa perlunya ada perubahan dalam metode pembelajarannya.

Pada siklus I pertemuan ke 2 guru mulai mencoba menerapkan metode Tanya jawab pada siswa, dengan penggunaan metode Tanya jawab ini siswa terlihat sudah mulai antusias dalam belajarnya, walaupun masih sedikit dari mereka yang mau bertanya dan masih belum beraninya siswa untuk menjawab.

Untuk siklus ke II pertemuan ke 3 guru mulai menerapkan metode diskusi dan Tanya jawab, pada pertemuan kali ini siswa terlihat sudah mulai aktif dalam belajarnya, terbukti dengan penerapan metode ini siswa bias meningkatkan belajar siswa. Sebelum aksi aktivitas rata-rata kelas $\mathrm{X}$ adalah $36,16 \%$. Dalam siklus yang saya maksud persentase indikator aktivitas siswa adalah $79,46 \%$ peningkatan pada siklus II sebesar 9,38\% menjadi 88,84. 
Keuntungan dari metode diskusi dalam belajar yaitu siswa lebih aktif dan belajar lebih banyak menyenangkan. ${ }^{13}$

Pada pertemuan kali ini juga guru berperan langsung sebagai pemimpin diskusi, karena belum adanya persiapan dari siswa untuk langsung menjadi moderator dalam sebuah diskusi, karena seorang guru pun harus mencontohkan apa yang perlu dilakukan dan ditiru muridnya.

Setelah siklus 2 pertemuan ke 3 selesai, guru melanjutkan pertemuan selanjutnya, dikarenakan pada pertemuan ke 3 kelompok sudah dibentuk dan pada pertemuan ke 4 kali ini guru langsung mengintruksi siswanya agar mulai berdiskusi. Pada pertemuan kali ini juga guru menerapkan metode diskusi dan Tanya jawab sekaligus, agar belajar bisa lebih efektif.

Dalam menerapkan metode ini guru juga membimbing siswa dalam melakukan diskusi kelompok. Hasil penelitian menunjukkan tingkat keaktifan siswa sebelum mendapat bimbingan kelompok $51,29 \%$ berada pada kategori rendah, setelah diberikan treatment berupa layanan bimbingan kelompok diperoleh keaktifan siswa dalam diskusi kelompok 70.2\% dengan kategori tinggi. ${ }^{14}$

Selain itu metode diskusi juga dapat melatih siswa agar selalu melakukan persiapan sebelum proses pembelajaran, seperti yang di paparkan dalam artikel

13 Sumiatie, "Penerapan Metode Diskusi untuk Meningkatkan Keaktifan Belajar Siswa dalam Pembelajaran Sejarah Kelas X di SMA PGRI 2 Palangka Raya", Vol. IV, 2 (Desember 2017), h. 103.

14 Mera Rizkina, “ Upaya Meningkatkan Keaktifan Siswa dalam Diskusi Kelompok melalui Layanan Bimbingan Kelompok pada Siswa Kelas VIII E Di SMPN I9 Semarang", (Skripsi, Fakultas Ilmu Pendidikan Universitas Negeri Semarang, Semarang, 2013), h. 55.

${ }^{15}$ Raden Rizky Amaliah, Abdul Fadhil , Sari Narulita, "Penerapan Metode Ceramah dan Diskusi dijelaskan: "untuk hasil pre test X-1 sendiri dapat dilihat pada pertemuan pertama berdasarkan nilai rata-rata kelas 84,5, Kemudian pada petemuan kedua 78,9 , sedangkan pada pertemuan ketiga 42,5. Hasil pre test untuk kelas X-4 pada pertemuan pertama berdasarkan nilai ratarata kelas yaitu 89,90 , sedangkan pada pertemuan kedua 82,13 , pada pertemuan ketiga 77. Berdasarkan kedua data tersebut dapat diambil kesimpulan bahwasanya kelas yang menggunakan metode diskusi memiliki persiapan yang lebih sebelum memulai proses pembelajaran daripada kelas yang menggunakan metode ceramah". 15

Begitupun dengan metode tanya jawab, metode ini pun sangat membantu siswa agar bisa aktif dalam belajarnya, Dengan tanya jawab, partisipasi siswa lebih besar dan mereka berusaha mendengarkan pertanyaan guru dengan baik dan mencoba memberikan jawaban yang tepat. ${ }^{16}$

\section{Hasil Belajar}

Berdasarkan paparan yang telah dijelaskan di atas, baik itu mulai dari tahap pra siklus sampai siklus ke II yang membahas mengenai pembelajaran dengan menggunakan metode diskusi dan tanya jawab untuk meningkatkan keaktifan belajar siswa, dapat dikemukakan hal - hal sebagai berikut:

Dalam Meningkatkan Hasil Belajar PAI di SMA Negeri 44 Jakarta". Jurnal Studi Al-Qur'an; Vol. 10, No. 2, . (2014), h. 125 (119- 131)

16 Sri mahdalena, "Penggunaan Metode Tanya Jawab Untuk Meningkatkan Hasil Belajar Siswa Pada Pembelajaran PKN Di Kelas V", artikel penelitian, (Program Studi Pendidikan Guru Sekolah Dasar Fakultas Keguruan Dan Ilmu Pendidikan Jurusan Pendidikan Dasar Universitas Tanjungpura Pontianak 2014), h. 4 


\section{Proses dan keaktifan siswa dalam belajar pada pra siklus}

Berdasarkan data hasil pengamatan pembelajaran pada pra siklus dapat disimpulkan hal-hal berikut .

a. Pada tahap ini rata - rata siswa belum terlalu bersemangat dalam belajarnya, terlihat dengan masih banyak nya siswa yang tak mau mendengarkan penjelasan guru, acuh tak acuh, sering izin keluar kelas dengan alasan yang bermacam macam, bahkan ada juga yang sampai tertidur dalam proses pembelajaran.

b. Masih pasifnya siswa dalam proses pembelajaran ketika menggunakan metode ceramah dan peta konsep, karena dengan metode ini siswa hanya menjadi pendengar setia.

c. Ketika guru mempersilahkan siswa untuk bertanya, masih sedikit sekali siswa yang berani untuk mengajukan pertanyaannya, siswa lebih memilih diam dan mendengar kesimpulan yang dipaparkan guru.Siswa ketika diberi kesempatan bertanya tidak ada yang menjawab.

Tabel 1. keaktifan siswa pada pra siklus

\begin{tabular}{|l|l|c|l|}
\hline No & Partisipan & Jumlah & $\mathbf{\%}$ \\
\hline 1. & Aktif & 2 & $7,14 \%$ \\
\hline 2. & Pasif & 18 & 64,28 \\
\hline 3. & Antusias & 3 & $10,71 \%$ \\
\hline 3. & Tidak masuk & 5 & $17,85 \%$ \\
\hline
\end{tabular}

Berdasarankan tabel di atas hasil pelajaran menggunakan metode ceramah dan peta konsep menunjukan bahwa siswa yang aktif masih sekitar 7, $14 \%$ sedangkan siswa yang tidak aktif mendapat prosentase 64, $28 \%$, dan siswa yang antusias dalam belajarnya sekitar $10,71 \%$, hal ini sangat miris sekali, maka dari itu untuk siklus selanjutnya dan pertemuan berikutnya guru mengusahakan memakai metode yang berbeda dalam proses pembelajaran agar bisa menambah antusias dan keaktifan belajar siswa.

\section{Proses dan keaktifan siswa dalam belajar pada siklus 1}

Berdasarkan data hasil pengamatan pembelajaran pada siklus I pertemuan ke 2 dapat disimpulkan hal-hal berikut.

a. Dengan menggunakan metode tanya jawab siswa sudah mulai terlihat aktif dalam belajarnya, sudah mulai terlihat siswa yang berani mengajukan pertanyaan dan menjawab pertanyaan dari guru.

b. Siswa mulai terlihat merespons penjelasan dari guru dan berkurangnya siswa yang mengantuk.

c. Siswa sudah mampu menjawab pertanyaan pertanyaan dari guru yang di tulis di papan tulis, walaupun masih terlihat siswa yang tetap jenuh dan masih banyak yang sering izin ke luar.

Tabel 2. keaktifan siswa pada siklus I pertemuan ke 2

\begin{tabular}{|l|l|l|l|}
\hline No & Partisipan & Jumlah & $\mathbf{\%}$ \\
\hline 1. & Aktif & 7 & $25 \%$ \\
\hline 2. & Pasif & 10 & $35,71 \%$ \\
\hline 3. & Antusias & 7 & $25 \%$ \\
\hline 4. & Tidak masuk & 4 & $14,28 \%$ \\
\hline
\end{tabular}

Dari pemaparan dari tabel di atas pembelajaran dengan menggunakan metode tanya jawab sudah mulai mengalami peningkatan, terlihat siswa yang aktif sudah meningkat sekitar $25 \%$, dan siswa yang pasif mengalami penurunan sekitar 35,71 \%, dan siswa yang antusias dalam belajarnya meningkat dari 10, $71 \%$ menjadi $25 \%$, dari hasil tersebut guru masih perlu melakukan inovasi agar keaktifan belajar siswa lebih meningkat. 


\section{Proses dan keaktifan siswa dalam belajar pada siklus II}

Berdasarkan data hasil pengamatan pembelajaran pada siklus II pertemuan ke 3 dan 4 dapat disimpulkan hal-hal berikut:

a. Pada siklus ke II ini guru mulai menerapkan metode diskusi, pada awal penerapan metode diskusi siswa masih belum terbiasa dengan metode tersebut, sehingga guru harus mencontohkannya terlebih dahulu.

b. Dengan penggunaan metode diskusi siswa bertambah antusias dalam belajarnya, dikarenakan dengan metode ini siswa dituntut untuk aktif dalam belajarnya.

c. Siswa dapat mulai berargumen dan menyampaikan pendapatnya masing masing, siswa sudah mulai mampu menjawab pertanyaan yang di lontarkan teman antar kelompoknya.

d. Siswa yang mengantuk sudah mulai berkurang, dan keaktifan siswa terlihat sudah meningkat pesat dibandingkan pertemuan pertemuan sebelumnya.

e. Siswa dapat menjawab pertanyaan pertanyaan yang di sampaikan guru, karena metode diskusi sekaligus tanya jawab menuntut siswa untuk melakukan persiapan terlebih dahulu sebelum proses pembelajaran dimulai.

Tabel 3. keaktifan siswa pada siklus II pertemuan ke 2 dan 3

\begin{tabular}{|l|c|c|l|}
\hline No & Partisipan & umlah & esentase \\
\hline 1. & Aktif & 15 & $53,57 \%$ \\
\hline 2. & Pasif & 2 & $7,15 \%$ \\
\hline 3. & Antusias & 8 & $28,57 \%$ \\
\hline 3. & Tidak masuk & 3 & $10,71 \%$ \\
\hline
\end{tabular}

${ }^{17}$ Tri Intan Sari, Yayuk Mardiati, Khutobah, "Penerapan Metode Diskusi dengan Menggunakan Media Gambar Untuk Meningkatkan Aktivitas dan Hasil Belajar Siswa kelas III dalam Pembelajaran PKN Tema Lingkungan di SDN Sumberlesung 02
Dari pemaparan tabel di atas, sudah terlihat bahwa siswa telah mengalami peningkatan keaktifan dan antusias siswa dalam belajarnya, jika di bandingkan dari tahap pra siklus sampai dengan siklus II keaktifan belajar siswa meningkat sekitar $46,42 \%$, Hal ini dibuktikan dengan aktifnya siswa dan antusias siswa dalam diskusi, berani menyampaikan argumen mereka masing masing dan menjawab pertanyaan pertanyaan dari guru. Maka, dengan adanya peningkatan ini peneliti menganggap cukup dalam melakukan penelitian pada siklus ke II saja, karena siswa sudah mengalami peningkatan keaktifan dalam belajarnya.

\section{Grafik 1. Perbandingan Keaktifan Pada Pra Siklus, Siklus I Dan Siklus II}

\section{Diagram Keaktifan Siswa}

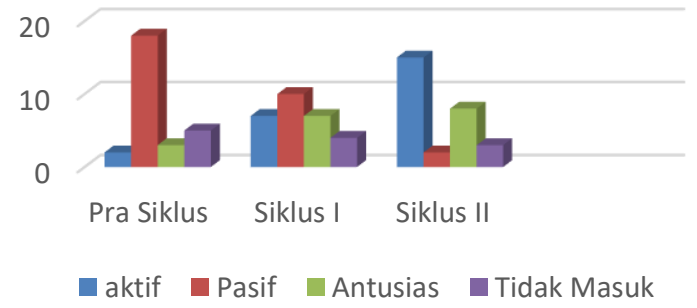

Selain siswa menjadi aktif dalam pelajaran dengan penggunaan metode diskusi dan metode tanya jawab, metode diskusi juga dapat meningkatkan hasil belajar pada siswa. ${ }^{17}$ Begitupun dengan penggunaan metode tanya jawab siswa akan lebih aktif jikalau guru memberikan stimulus stimulus berupa pertanyaan pertanyaan, dan dengan tanya jawab siswa akan merespons pertanyaan dari guru. ${ }^{18}$ Apabila kedua metode ini dipadukan hal ini tentu sangat membantu dalam menunjang keberhasilan dalam proses pembelajaran.

Ledokombo Jember", Jurnal Edukasi Unej, Vol. 1. No. 2 (2014), h. 36.

18 Sri mahdalena, "Penggunaan Metode

Tanya Jawab,, h. 12. 


\section{Kesimpulan}

Dari uraian yang sudah dipaparkan di atas dan juga melihat rumusan masalah yang sudah ditetapkan, penulis dapat mengambil kesimpulan sebagai berikut:

1. Dalam penerapan metode pembelajaran tanya jawab siswa bertambah antusias dalam belajarnya walaupun dengan penggunaan metode ini sedikit siswa yang aktif.

2. Penerapan metode tanya jawab dan diskusi yang berlangsung berlangsung pada siklus I dan II pertemuan ke 2 sampai ke 4 dengan melakukan diskusi kelompok terlebih, melakukan tanya jawab antar kelompok kemudian melakukan diskusi bersama dengan menunjuk salah satu siswa sebagai moderatornya.

3. Dengan penerapan metode diskusi dan tanya jawab siswa sangat antusias dalam belajarnya dalam siklus I pertemuan pertama terlihat siswa masih ada yang mengantuk acuh tak acuh dan sebagainya tetapi pada siklus II pertemuan ke 2 dan seterusnya siswa mengalami keaktifan belajar dan keaktifan tersebut meningkat mulai dari tahap pra siklus sekitar 7,14 \% sampai dengan siklus II menjadi 53,57 \%, dalam hal ini siswa telah mengalami peningkatan keaktifan dalam belajarnya sekitar 46,42 \%.

\section{Daftar Pustaka}

Arief, Armai . Pengantar Ilmu dan Metodologi Pendidikan Islam, Jakarta: Ciputat Pres, 2002.
Kuntowijoyo. Pengantar Ilmu Sejarah. Yogyakarta : Yayasan Bintang Budaya, 1995.

Kususmah, Wijaya dan Dedi Dwitagama. Mengenal Penelitian Tindakan Kelas Jakarta: PT Indeks, 2012.

Intan Sari, Tri. dkk. " Penerapan Metode Diskusi dengan Menggunakan Media Gambar Untuk Meningkatkan Aktivitas dan Hasil Belajar Siswa kelas III dalam Pembelajaran PKN Tema Lingkungan di SDN Sumberlesung 02 Ledokombo Jember", Jurnal Edukasi Unej, Vol. 1. No. 2 (2014).

Mahdalena, Sri. “Penggunaan Metode Tanya Jawab Untuk Meningkatkan Hasil Belajar Siswa Pada Pembelajaran PKN Di Kelas V", artikel penelitian, (Program Studi Pendidikan Guru Sekolah Dasar Fakultas Keguruan Dan Ilmu Pendidikan Jurusan Pendidikan Dasar Universitas Tanjungpura Pontianak 2014.

Rachman Shaleh, Abdul. Pendidikan Agama dan Keagamaan, Jakarta Pusat: PT. Gemawindu Pancaperkasa, 2000.

Rizkina, Mera. “ Upaya Meningkatkan Keaktifan Siswa dalam Diskusi Kelompok melalui Layanan Bimbingan Kelompok pada Siswa Kelas VIII E Di SMPN I9 Semarang", (Skripsi, Fakultas Ilmu Pendidikan Universitas Negeri Semarang, Semarang, 2013.

Rizky Amaliah, Raden dkk. "Penerapan Metode Ceramah dan Diskusi Dalam Meningkatkan Hasil Belajar PAI di SMA Negeri 44 Jakarta". Jurnal Studi Al-Qur'an; Vol. 10, No. 2, . (2014), (119-131)

Sardiman. Interaksi dan Motivasi Belajar Mengajar. Rajawali, Jakarta. 2004.

Soetopo, Hendyat. Pendidikan Dan Pembelajaran, Malang: UMM Press, 2005. 
Iurnal Pendidifan dan Studi Keislaman

Sumarni, Abduh Harun, dan Imran. "Penerapan Metode Diskusi Untuk Meningkatkan Hasil Belajar Siswa Kelas IV Sekolah Dasar Kecil Toraranga Pada Mata Pelajaran PKn Pokok Bahasan Sistem Pemerintahan Kabupaten, Kota dan Provinsi". Jurnal Kreatif Tadulako Online Vol. 3 No. 4. (2015).

Suryana, Asep dan Suryadi. Pengelolaan Pendidikan, Jakarta: Direktorat Jenderal Pendidikan Islam Departemen Agama Republik Indonesia, 2009), Cet. I. 